\title{
Differentiated thyroid cancer cell invasion is regulated through epidermal growth factor receptor-dependent activation of matrix metalloproteinase (MMP)-2/gelatinase A
}

\author{
Michael W Yeh, Jean-Philippe Rougier', Jin-Woo Park, Quan-Yang Duh, \\ Mariwil Wong, Zena Werb ${ }^{1}$ and Orlo H Clark
}

\begin{abstract}
Endocrine Surgery Laboratory, UCSF/Mt. Zion Medical Center, San Francisco, California 94115, USA ${ }^{1}$ Department of Anatomy, University of California San Francisco, San Francisco, California 94143, USA

(Requests for offprints should be addressed to O H Clark, Department of Surgery, C-342, 1600 Divisadero St., San Francisco, California 94115, USA; Email: myeh@mednet.ucla.edu)
\end{abstract}

M W Yeh is now at Endocrine Surgical Unit, Division of General Surgery, David Geffen School of Medicine at UCLA, 10833 Le Conte Avenue 72-228 CHS, Los Angeles, California 90095, USA

\begin{abstract}
Mechanisms of invasion in thyroid cancer remain poorly understood. We hypothesized that signaling via the epidermal growth factor receptor (EGFR) stimulates thyroid cancer cell invasion by altering the expression and cleavage of matrix metalloproteinases (MMPs). Papillary and follicular carcinoma cell lines were treated with EGF, the EGFR tyrosine kinase inhibitor AG1478, and the MMP inhibitors GM-6001 and Col-3. Flow cytometry was used to detect EGFR. In vitro invasion assays, gelatin zymography, and quantitative reverse transcription-PCR were used to assess the changes in invasive behavior and MMP expression and activation. All cell lines were found to overexpress functional EGFR. EGF stimulated invasion by thyroid cancer cells up to sevenfold $(P<0.0001)$, a process that was antagonized completely by AG1478 and Col-3, partially by GM-6001, but not by the serine protease inhibitor aprotinin. EGF upregulated expression of MMP-9 (2.64- to 8.89-fold, $P<0.0001$ ) and membrane type-1 MMP (MT1-MMP, 1.97- to 2.67 -fold, $P<0.0001$ ). This effect was blocked completely by AG1478 and partially by Col-3. The activation of MMP-2 paralleled MT1-MMP expression. We demonstrate that MMPs are critical effectors of invasion in the papillary and follicular thyroid cancer cell lines studied. Invasion is regulated by signaling through EGFR, an effect mediated by augmentation of gelatinase expression and activation. MMP inhibitors and growth factor antagonists may be effective tumoristatic agents for the treatment of aggressive thyroid carcinomas.
\end{abstract}

Endocrine-Related Cancer (2006) 13 1173-1183

\section{Introduction}

The incidence of thyroid cancer is rising rapidly (Hodgson et al. 2004). Chemo- and radiotherapy have limited utility in the treatment of aggressive thyroid cancers (Haugen 1999), highlighting a need for the development of novel therapies. Matrix metalloproteinases (MMPs) promote tumor progression by degrading normal barriers to invasion (Johansson et al. 2000). Thyroid carcinomas produce elevated levels of MMP-2, and MMP-2 activation correlates with the presence of lymph node metastases (Nakamura et al. 1999). Despite preclinical data supporting the use of MMP inhibitors in cancer treatment, clinical trials involving these agents have had disappointing results (Coussens et al. 2002), suggesting that the manipulation of MMPs to achieve tumor stasis may require altering the expression or activity of MMPs rather than global inhibition. 
Overexpression of the epidermal growth factor receptor (EGFR) has been associated with tumor aggressiveness (Nicholson et al. 2001). Clinical trials involving EGFR antagonists have shown some effectiveness against solid tumors and may only be beneficial against the subset of tumors whose progression is highly dependent on EGFR signaling (Dancey \& Freidlin 2003). EGFR signaling is likely to be important in thyroid cancer for several reasons: (1) the thyroid is an EGF-rich environment (Kajikawa et al. 1991); (2) the presence of erb-B family receptors has been demonstrated in thyroid tumors (Haugen et al. 1992, Akslen \& Varhaug 1995); and (3) stimulation of thyroid cancer cells with EGF is known to enhance invasion in vitro (Hoelting et al. 1994, Zielke et al. 1999).

We investigated the expression of EGFRs in thyroid cancer cell lines and examined the ability of MMP inhibitors and the EGFR tyrosine kinase inhibitor AG1478 to reduce EGF-stimulated invasion in vitro. Tetracycline derivatives such as Col-3 act by blocking both the production and the activity of MMPs (Hanemaaijer et al. 1998), in contrast to other known MMP inhibitors (such as GM-6001, used here), which act by enzyme inhibition alone. Our results indicate that MMPs are important contributors to thyroid cancer cell invasion, EGFR signaling augments invasion via induction of MMP expression and activation, and potent anti-invasive effects can be achieved by inhibiting MMP expression.

\section{Materials and methods}

\section{Cell culture and reagents}

The human thyroid carcinoma cell lines were maintained in DMEM/F12 (Mediatech, Inc., Herndon, VA, USA) with $10 \%$ fetal bovine serum, $200 \mathrm{mM} \mathrm{L}$-glutamine, $10 \mathrm{mIU} / \mathrm{ml}$ human thyrotropin, and $10 \mu \mathrm{g} / \mathrm{ml}$ insulin. Experiments were carried out in H5 media: DMEM/F12 supplemented with $200 \mathrm{mM}$ L-glutamine, $10 \mu \mathrm{g} / \mathrm{ml}$ insulin, $5 \mu \mathrm{g} / \mathrm{ml}$ transferrin, $10 \mathrm{mg} / \mathrm{ml}$ somatostatin, $2 \mathrm{ng} / \mathrm{ml}$ gly-his-lys, and $360 \mathrm{pg} / \mathrm{ml}$ hydrocortisone. Human follicular carcinoma cell lines were derived from the same patient: follicular thyroid carcinoma (FTC)-133 from the primary tumor, FTC-236 from a lymph node metastasis, and FTC-238 from a pulmonary metastasis. TPC-1 (papillary), XTC-1 (Hürthle cell), and ARO-82-1 (anaplastic) carcinoma cell lines have been previously characterized (Wright et al. 1991, Fagin et al. 1993, Jossart et al. 1996, Zielke et al. 1998). Cells lines were used between passages 5 and 20, and experiments were performed in serum-free media after a $24 \mathrm{~h}$ period of serum deprivation. Normal human thyrocyte primary cultures were derived from fresh surgical specimens. Samples were digested with collagenase $(25 \mathrm{mg} / \mathrm{ml})$, filtered through a $70 \mu \mathrm{M}$ pore nylon strainer, then grown in maintenance media as described previously. When necessary, cultures were enriched in thyrocytes using thyrotropin and geneticin (a selective fibroblast toxin). Cultures $>95 \%$ pure by microscopy were used.

Reagents and chemicals were purchased from Sigma unless otherwise specified. GM-6001 (Chemicon International, Inc., Temecula, CA, USA) and Col-3 (CollaGenex Pharmaceuticals, Newtown, PA, USA) were administered in dimethylsulfoxide vehicle solutions. Cells were treated for $0-48 \mathrm{~h}$ and all the experimental and control groups were done in triplicate.

\section{Flow cytometric analysis}

Direct immunofluorescence labeling for surface EGFRs was performed with anti-EGFR mouse monoclonal antibody conjugated to R-phycoerythrin (PE, BD Pharmingen, San Diego, CA, USA). Cells were harvested using trypsin, washed, and incubated with anti-EGFR antibody. After an additional wash, $10 \mu \mathrm{l}$ propidium iodide (PI) were added to each sample. Cells were analyzed using a FACSCalibur flow cytometer (Becton Dickinson, San Jose, CA, USA). Flow data were back-gated on EGFR positive cells to determine optimal forward and orthogonal light scatter gates. EGFR-PE intensity was determined after both forward scatter versus orthogonal scatter gating (to exclude debris and cell clumps) and PI-negative gating (to exclude dead or late apoptotic cells) were performed. At least 10000 events were collected per sample. Mean fluorescence intensity was determined for each sample and its corresponding autofluorescent controls.

\section{Western blot analysis}

Western blotting for EGFR was performed by subjecting $25 \mu \mathrm{g}$ protein extract of total cell lysate to electrophoresis on $8 \%$ polyacrylamide gels. Gels were transferred to nitrocellulose membranes, which were blocked using 5\% nonfat dry milk in $10 \mathrm{mM}$ Tris- $\mathrm{NaCl}$ buffer and then probed with anti-EGFR mouse monoclonal antibody (Oncogene Research Products, Inc., Cambridge, MA, USA) diluted in the ratio of 1:1000. After washing, membranes were incubated for $1 \mathrm{~h}$ with horseradish peroxidase-conjugated goat antimouse IgG antibodies (Sigma-Aldrich Corp.) diluted in the ratio of 1:1000. Bands were visualized using enhanced chemiluminescence solution and quantified using scanning densitometry. 


\section{Proliferation assay}

Relative cell mass was determined using the dimethylthiazol-diphenyltetrazolium bromide (MTT) method, as previously described (Mosmann 1983). Cells were treated with $400 \mu \mathrm{g} / \mathrm{ml}$ MTT 400 and incubated at $37^{\circ} \mathrm{C}$ for $3 \mathrm{~h}$. Formazan, the colored metabolite of MTT, was solubilized in a solution of $0.04 \mathrm{M} \mathrm{HCl}$ and 3\% SDS in isopropanol. The optical density was then read using a microplate reader (Molecular Devices, Sunnyvale, CA, USA) at wavelengths of 595 and $630 \mathrm{~nm}$ (1-reference).

\section{Invasion assay}

Invasion chambers were prepared by coating the upper surface of a $6.5 \mathrm{~mm}$ Costar Transwell $(8 \mu \mathrm{M}$ pore size, Corning, Inc., Corning, NY, USA) with a thin layer $(50 \mu \mathrm{l})$ of reconstituted basement membrane (Growth Factor Reduced Matrigel, BD Biosciences, Bedford, MA, USA), diluted 1:5 in serum-free media, as previously described (Albini et al. 1987). One lakh and fifty thousand cells were used per chamber. Invading cells were defined as those able to penetrate the Matrigel and migrate through the polycarbonate membrane. Percentage invasion was determined by harvesting invading cells (lower chamber) and noninvading cells (upper chamber) and quantifying cell mass using MTT as previously described. This quantification method was confirmed by staining cells adherent to the underside of the membrane with a modified Wright stain (Diff-Quik) followed by cell counting under $112.5 \times$ magnification using a Nikon SMZ-1500 stereomicroscope.

\section{Gelatin zymography}

MMP activity in the cell-culture supernatants was analyzed by gelatin gel electrophoresis, as previously described (Behrendtsen et al. 1992). Unreduced samples were applied on $8 \%$ polyacrylamide gels containing $1 \mathrm{mg} / \mathrm{ml}$ gelatin. After electrophoresis, gels were washed, incubated in substrate buffer $(50 \mathrm{mM}$ Tris ( $\mathrm{pH} 7.5$ ), $5 \mathrm{mM} \mathrm{CaCl}_{2}, 1 \mathrm{mM} \mathrm{ZnCl}_{2}$, and $0.01 \%$ azide $(\mathrm{w} / \mathrm{v}))$ for $24 \mathrm{~h}$ at $37{ }^{\circ} \mathrm{C}$, and stained with $0.5 \%$ Coomassie Brilliant Blue (prepared in $30 \%$ ethanol, $10 \%$ acetic acid, and $1 \%$ formaldehyde). The presence of metalloproteinases was indicated by unstained proteolytic zones of the substrate. Both active and inactive forms are revealed by this technique as exposure of proenzyme to SDS during gel separation leads to activation without proteolytic cleavage (Hipps et al. 1991). All zymograms presented in figures are representative of at least three independent experiments performed in triplicate cultures. Samples were normalized to cell number. Gelatinase activities were quantified by scanning densitometry and ChemiImager 4000 software (Alpha Innotech Corporation, San Leandro, CA, USA). A linear relationship was established between enzyme concentration and band intensity (Salo et al. 1991). The MMP-2 activation ratio was calculated by dividing the amount of active MMP-2 by the sum of active and pro-MMP-2.

\section{Quantitative real-time reverse transcription-PCR}

Total RNA was extracted with TRIzol reagent (Gibco BRL), using the manufacturer's protocol. Randomly primed cDNA was synthesized with Moloney murine leukemia virus reverse transcriptase (Gibco BRL), using $0.125 \mu \mathrm{g}$ total RNA per $100 \mu \mathrm{l}$ reaction. Quantitative real-time PCR (qRT-PCR) was performed on cDNA samples using dual-labeled fluorogenic probes and an ABI Prism 7700 Sequence Detection System (Taqman, Applied Biosystems, Foster City, CA, USA), as previously described (Heid et al. 1996). Oligonucleotides were obtained from Biosearch Technologies, Inc., Novato, CA, USA. Primer/probe sets were designed using Primer Express software (Applied Biosystems) and are listed in the following sequence: forward primer, reverse primer, Taqman probe. MMP-2: 5' CGCTCAGATCCGTGGTGAG 3', $5^{\prime}$ CATCAATCTTTTCCGGGAGCT $3^{\prime}, 5^{\prime}$ 6-FAMCTTCAAGGACCGGTTCATTT GGCG-6-carboxytetramethyl-rhodamine (TAMRA) $3^{\prime}$. MMP-9: $5^{\prime}$ ACGCAGACATCGTCATCCAGT $3^{\prime}, 5^{\prime}$ CCACA ACTCGTCATCGTCGA $3^{\prime}, 5^{\prime}$ 6-FAM-TGGTGTCGCGGAGCACGGA-TAMRA $3^{\prime}$. Membrane type-1 MMP (MT1-MMP): 5' TACGTACCCACACACAGC GC $3^{\prime}, 5^{\prime}$ TGTCTGGAACACCACATCGG $3^{\prime}, 5^{\prime}$ 6-FAM-CACCATGAAGGCCATGAGGCG-TAMRA $3^{\prime}$. tissue inhibitor of metalloproteinases (TIMP)-1: $5^{\prime}$ CTGGCTTCTGGCATCCTGTT 3', 5' GGTGGTCTGG TTGACTTCTGGT $3^{\prime}, 5^{\prime}$ 6-FAM-CCGACCTCGTCATCAGGGCCAAG-TAMRA $3^{\prime}$. TIMP-2: $5^{\prime}$ TGTGACTTCATCGTGC CCTG $3^{\prime}, 5^{\prime}$ TGTAGCACGGGATCATGGG 3', 5' 6-FAM-TGCGAGTGCAAGATCACGCGC-TAMRA $3^{\prime}$. Human $\beta$-glucuronidase was used as a reference gene; the following oligonucleotides were used for its detection: $5^{\prime}$ CTCATTTGGAATTTGCCGATT $3^{\prime}$, 5' CCGAGTGAAGATCC CCTTTT TA $3^{\prime}, 5^{\prime}$ 6-FAM-TGAACAGTCACCGACGAGAGTGCTGG-TAMRA $3^{\prime}$.

Optimal PCR conditions and PCR efficiency were determined empirically. PCR was conducted in triplicate with $50 \mu$ l reaction volumes of $1 \times \mathrm{PCR}$ 
buffer (Applied Biosystems), $5.5 \mathrm{mM} \mathrm{MgCl}_{2}$, $200 \mathrm{mM}$ of each deoxyNTP, and $0.025 \mathrm{U} / \mu \mathrm{l} \mathrm{Ampli-}$ Taq Gold (Applied Biosystems), with $10 \mu \mathrm{l}$ cDNA (described previously). A mixture of $500 \mathrm{nM}$ forward and reverse primer plus $200 \mathrm{nM}$ probe was added to each chamber and PCR was performed using the following cycle parameters: 1 cycle of $95^{\circ} \mathrm{C}$ for $12 \mathrm{~min}$ and 45 cycles of $95^{\circ} \mathrm{C}$ for $15 \mathrm{~s}, 60^{\circ} \mathrm{C}$ for $1 \mathrm{~min}$. The difference in cycle threshold $\left(C_{\mathrm{t}}\right.$, number of PCR cycles required for 6-carboxy fluorescein (FAM) intensities to exceed a threshold just above background) between test gene and reference gene was determined and designated $\Delta C_{\mathrm{t}} . \Delta C_{\mathrm{t}}$ values for test genes in treated cells were then subtracted from $\Delta C_{\mathrm{t}}$ values in control cells to yield $\Delta \Delta C_{\mathrm{t}}$. Relative copy number was then calculated using the following formula:

Relative cDNA copy number $=(1+E)^{-\Delta \Delta C_{t}}$

where $E$ represents PCR efficiency.

\section{Statistical analysis}

Flow cytometry data were analyzed using the Kolmogorov-Smirnov test. Data from proliferation and invasion assays were analyzed using singleclassification ANOVA followed by post hoc testing using the Bonneferroni/Dunn method. $\Delta \Delta C_{\mathrm{t}}$ values generated from quantitative real-time PCR were treated in a similar fashion. Band intensities from gelatin zymograms were analyzed using the KruskalWallis test after the values were normalized with respect to control band intensity on individual gels. Pairwise comparisons were made using the MannWhitney $U$-test.

\section{Results}

\section{Thyroid cancer cells overexpress functional EGF receptors}

Direct labeling and flow cytometric analysis revealed that all the six thyroid cancer cell lines studied express cell surface EGFRs at high levels (Fig. 1A). Normal thyroid cells showed significant heterogeneity with respect to both autofluorescence and EGFR surface expression (Fig. 1B). Frequency distributions of stained cells versus autofluorescent controls were significantly different in all cases $(P<0.001)$. Differential mean fluorescence intensity (stained cells minus controls) for the malignant cell lines was, on average, greater than those of the normal thyroid samples $(113.72$ vs $57.38, P<0.05)$. Treatment of cells with EGF for $24 \mathrm{~h}$ resulted in downregulation of EGFR from the cell surface, suggesting receptor internalization and, thus, the presence of functional receptors (data not shown). Western blotting confirmed overexpression of EGFR by thyroid cancer cells, which displayed EGFR levels approximately twice that of normal controls (data not shown).

\section{EGFR activation stimulates invasion}

Invasion was assessed $48 \mathrm{~h}$ post-treatment for all cell lines. The follicular and papillary carcinoma cell lines displayed an invasive phenotype and a robust response to EGF $(10 \mathrm{ng} / \mathrm{ml})$, with 1.3 - to 7 -fold increases in invasion observed (Figs 2 and 3). FTC238 cells displayed low baseline invasiveness but were highly sensitive to EGF, as the addition of only $1.0 \mathrm{ng} / \mathrm{ml}$ EGF elicited a significant increase in invasion (data not shown). TPC-1 cells displayed the highest baseline invasiveness (30\%) and responded to EGF with a lower but significant increase in invasion (1.3-fold). ARO-82-1 cells displayed 5-10\% invasion irrespective of treatment, and XTC-1 cells were found to be minimally invasive $(<1.5 \%$ invasion $)$.

EGF did not significantly affect cell proliferation or death under the conditions used, which involved low (20\%) initial plating densities and a short time course. Both untreated and EGF-treated cells displayed exponential growth with a doubling time of 36-48 h, suggesting that the increased invasiveness caused by EGF is not related to increased cell proliferation in our model.

Treatment of follicular and papillary carcinoma cell lines with AG1478 $(2 \mu \mathrm{M})$ abolished EGF-stimulated invasion (Figs 2 and 3). Invasion by cells treated with EGF + AG1478 was not significantly different from that by cells treated with AG1478 alone, indicating complete inhibition of EGFR tyrosine kinase activity at this dose. AG1478 reduced invasion by TPC-1 cells to $9 \%$ below control, suggesting the presence of endogenous EGFR activity at baseline. AG1478 had no effect on cell growth or survival.

\section{MMP inhibition reduces invasion and mimics EGFR blockade}

Both GM-6001 $(100 \mu \mathrm{M})$ and Col-3 (5 and $10 \mu \mathrm{g} / \mathrm{ml})$ reduced EGF-stimulated invasion, though more potent effects were seen with Col-3 (Figs 2 and 3). Higher doses of GM-6001 were cytotoxic and difficult to achieve due to limited solubility. The effect of Col-3 paralleled that of AG1478, with one exception: $10 \mu \mathrm{g} / \mathrm{ml} \mathrm{Col-3}$ had a greater anti-invasive effect in 
FTC-133 cells. This cell line was more sensitive to the cytotoxic effects of Col-3 than the others, as a dose of $10 \mu \mathrm{g} / \mathrm{ml}$ caused a $22 \%$ reduction in cell mass at $48 \mathrm{~h}$ (3\% apoptosis and 19\% necrosis). Col-3 was not
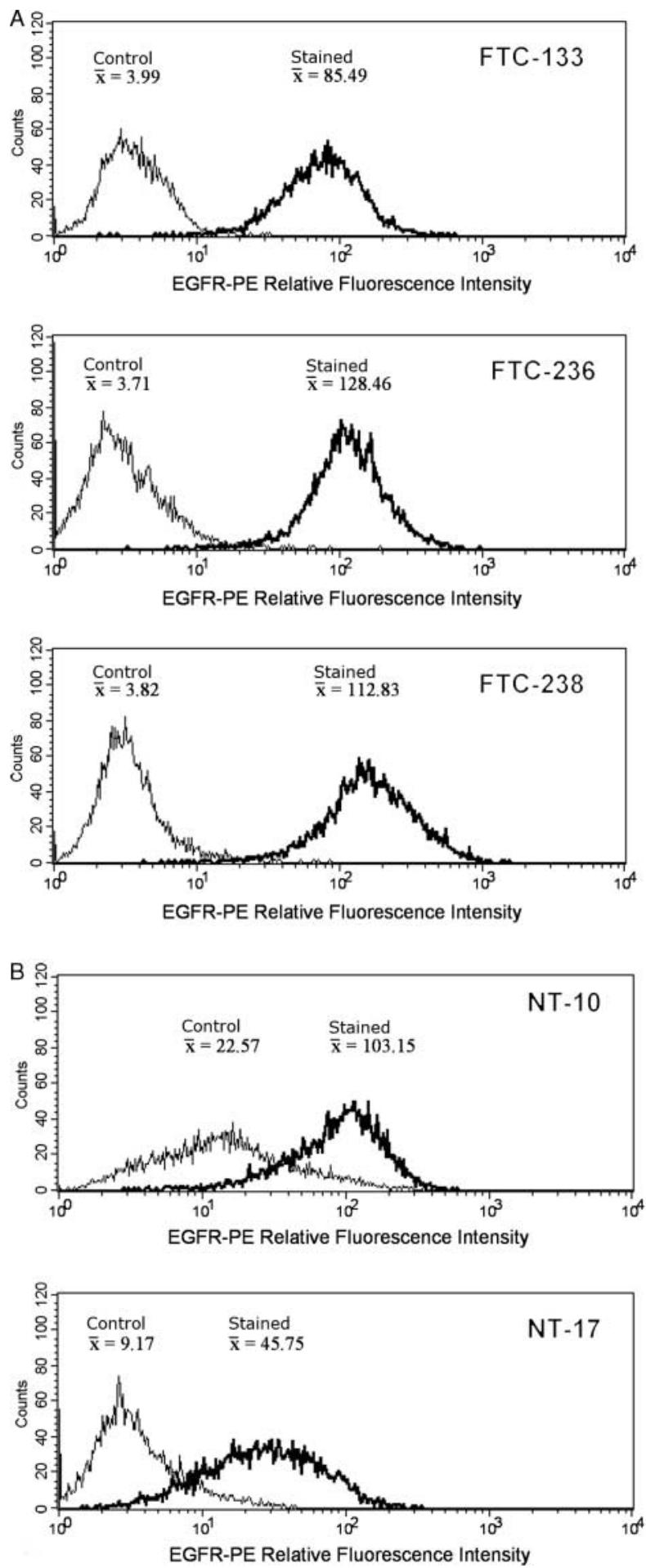

cytotoxic to the other cell lines. Further experiments demonstrated that the serine protease inhibitor aprotinin had no effect on EGF-stimulated invasion, even at high doses ( $>1$ T.I.U.).
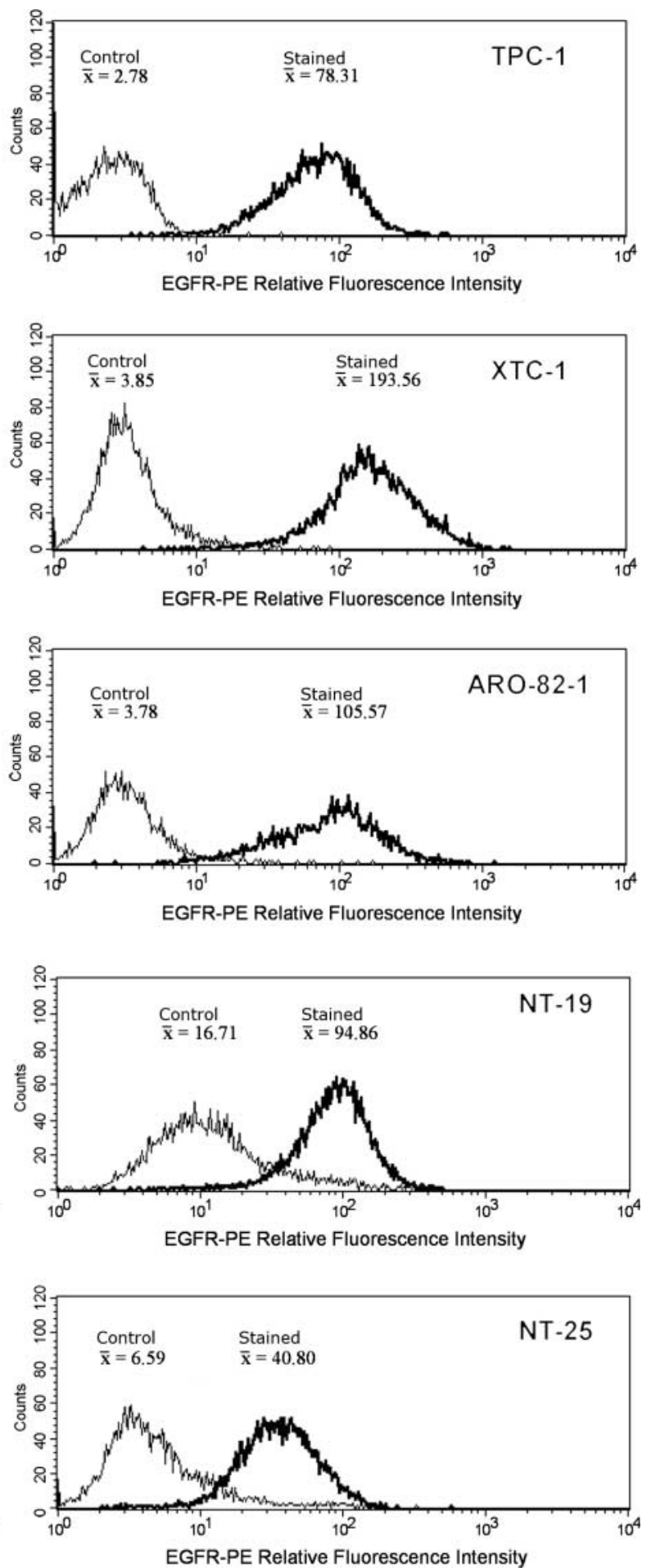

Figure 1 EGF receptor surface expression in (A) thyroid cancer cell lines and (B) normal thyroid primary cultures. $Y$-axis, cell count; $X$-axis, log relative fluorescence intensity. Figures show stained samples with matched negative controls. Mean fluorescence intensities for all samples are shown above the corresponding histograms. 

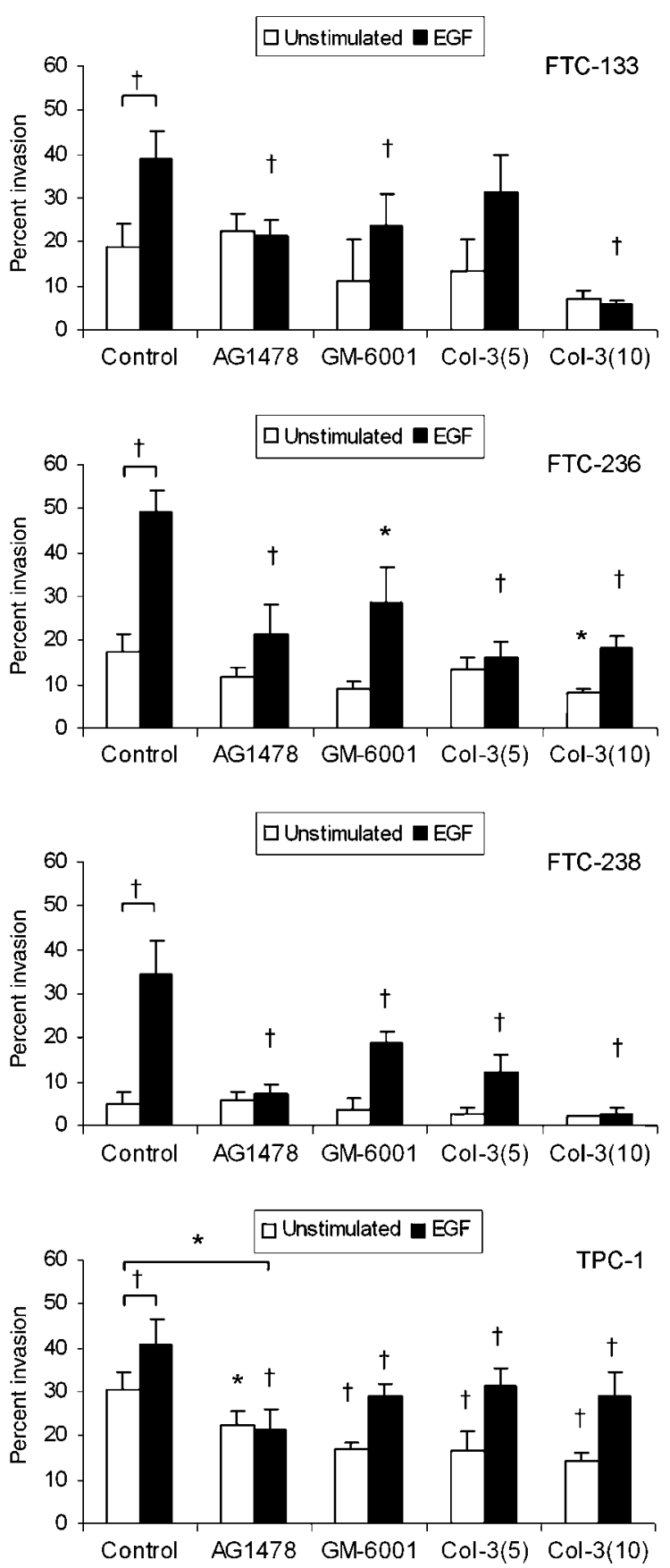

Figure 2 Invasion by thyroid cancer cells treated with EGF, AG 1478 , and MMP inhibitors. Cells were cultured with $10 \mathrm{ng} / \mathrm{ml}$ EGF, $2 \mu \mathrm{M}$ AG 1478, and $100 \mu \mathrm{M}$ GM-6001. Col-3 dosages are indicated in microgram per milliliter. Figures reflect pooled data from two or more experiments performed in triplicate cultures. Data expressed as mean \pm 1 s.D. Brackets indicate pairwise comparisons. Unbracketed asterisk and dagger denote comparisons made to control. ${ }^{\star} P<0.005,{ }^{\dagger} P<0.0001$ by ANOVA.

\section{EGF-mediated activation of MMP-2 is blocked completely by AG1478 and partially by Col-3}

The activity of gelatinases released by thyroid cancer cells was determined by gelatin zymography (Fig. 4). FTC cell lines secreted pro-MMP-2 in the absence of EGF. In FTC-133 cells, EGF $(10 \mathrm{ng} / \mathrm{ml})$ stimulated the cleavage of pro-MMP-2 (72 kDa band) into active MMP2 (62 kDa band) with an activation ratio (AR) of $0.34 \pm$ 0.04 , without increasing the total amount of MMP-2 detected. A similar pattern was seen in FTC-236 and FTC-238 cells, where EGF increased the amount of active MMP-2 present (FTC-236: AR $0.25 \pm 0.03$ vs $0.11 \pm 0.01, P<0.05$; FTC-238: AR $0.24 \pm 0.02$ vs $0.15 \pm 0.01, P<0.05)$. These changes on zymography were correlated with a 1.97 - to 2.67 -fold increase in MT1-MMP expression in EGF-stimulated FTC cell lines, as measured by qRT-PCR (Fig. 5). The addition of AG1478 completely reversed all EGF-related changes in MMP-2 activation and MT1-MMP expression. Col-3 caused a variable reduction in EGF-stimulated MT1MMP expression, which corresponded to a dosedependent partial inhibition of MMP-2 activation in FTC-236 cells ( $21.4 \%$ reduction in AR by Col-3, $5 \mu \mathrm{g} / \mathrm{ml}$ and $29.2 \%$ by $10 \mu \mathrm{g} / \mathrm{ml}, P<0.05)$ and FTC-238 cells (34.4\% reduction in AR by Col-3, $5 \mu \mathrm{g} / \mathrm{ml}$ and $53.6 \%$ by $10 \mu \mathrm{g} / \mathrm{ml}, P<0.05)$. MMP-2 activation was not affected by Col-3 in FTC-133 cells.

TPC-1 cells secreted significant quantities of MMP2 in both pro- and active forms (Fig. 4). In this cell line, EGF had no effect on MMP-2 release or activation as measured by zymography. However, MMP-2 and MT1-MMP expressions were increased by EGF at the mRNA level (Fig. 5), and these alterations were reversed by both AG1478 and Col-3.

\section{EGF-mediated expression of MMP-9 is blocked completely by AG1478 and partially by Col-3}

In contrast to the other genes studied, MMP-9 was expressed at low levels in all cell lines (Figs 4 and 5). Only the FTC-238 and TPC-1 cell lines displayed significant MMP-9 activity on zymography. In FTC238 cells, EGF increased total MMP-9 release to 1.24 times that of control $(P<0.05)$ without altering activation, an effect that was antagonized by both AG1478 and Col-3 (10 $\mu \mathrm{g} / \mathrm{ml})$. In TPC-1 cells, EGF increased the release of pro-MMP-9 to 1.7 times that of control $(P<0.05)$. The addition of AG1478 completely antagonized this effect and reduced pro-MMP-9 activity to below control levels ( 0.69 times control, $P<0.05)$. Col-3 $(10 \mu \mathrm{g} / \mathrm{ml})$ caused a $41.5 \%$ reduction in pro-MMP-9 activity $(P<0.05)$. qRT-PCR demonstrated significant EGF-induced elevations in MMP-9 


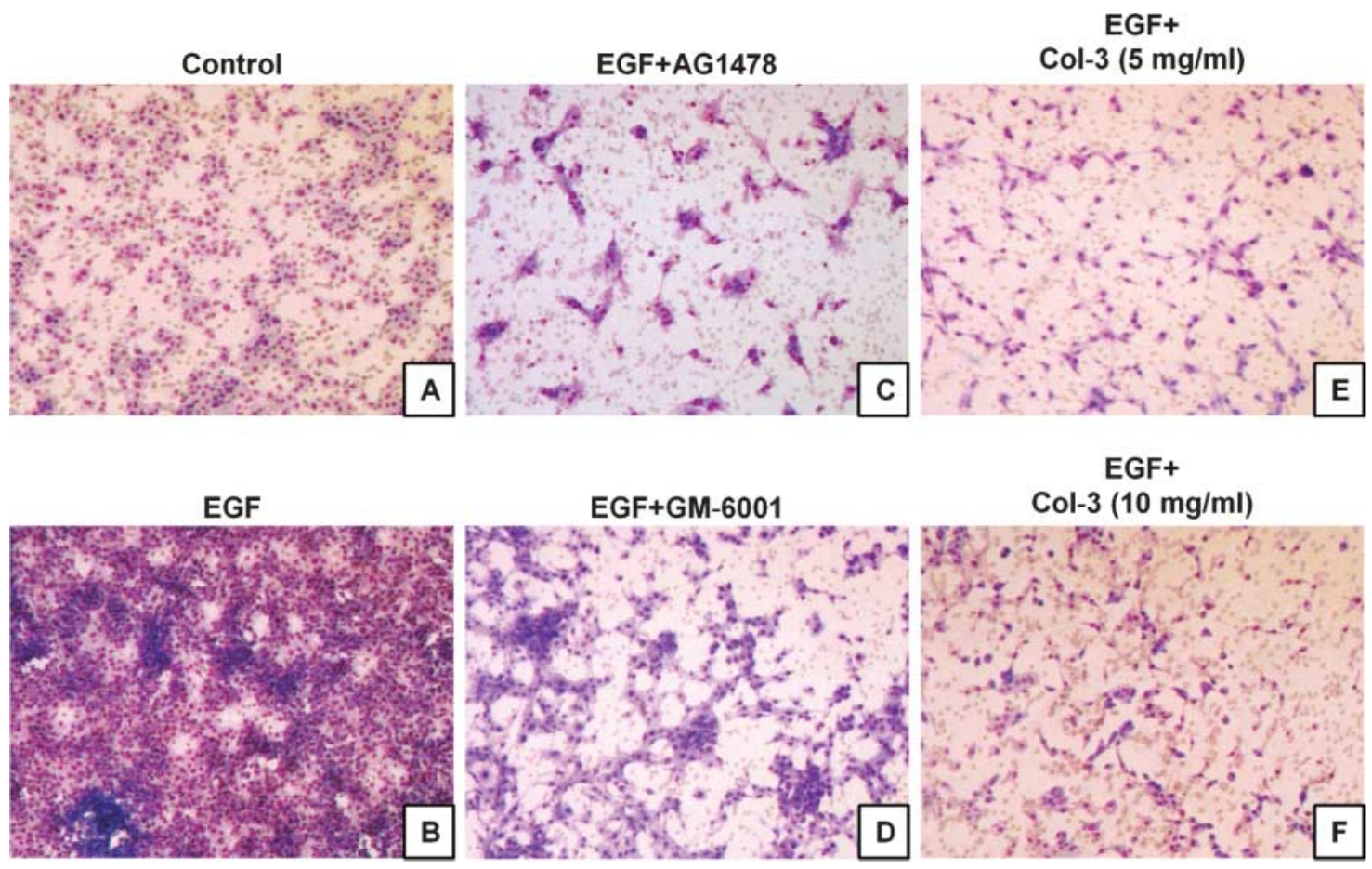

Figure 3 Photomicrographs of invasive FTC-236 cells. (A) Control, (B) EGF (10 ng/ml), (C) EGF plus AG1478 (2 $\mu$ M), (D) EGF plus GM-6001 $(100 \mu \mathrm{M})$, (E) EGF plus Col-3 $(5 \mu \mathrm{g} / \mathrm{ml})$, (F) EGF plus Col-3 $(10 \mu \mathrm{g} / \mathrm{ml})$. Cells were stained with a modified Wright stain (Diff-Quik) and are shown here at $112.5 \times$ magnification. Pores of $8 \mu \mathrm{M}$ in the polycarbonate membrane are visible in the background.

expression (2.64- to 8.89-fold), which were blocked completely by AG1478 and to a varying degree by Col-3. Zymography was insufficiently sensitive to detect parallel changes at the protein level in many cases.

\section{EGF augments TIMP-1 expression in follicular cancer cells}

In all FTC cell lines, EGF significantly increased expression of TIMP-1 (1.56- to 2.87-fold), an effect that was antagonized by AG1478. Col-3 had no effect on EGF-induced TIMP-1 expression. TIMP-2 expression was not affected by any of the above treatments.

\section{Discussion}

Thyroid carcinomas arise and grow in an EGF-rich environment, and the expression of EGFRs in these tumors is a negative prognostic indicator (Akslen \& Varhaug 1995). Here, we demonstrate overexpression of functional surface EGFRs in malignant thyroid cells and show that EGFR tyrosine kinase activation stimulates invasion by follicular (FTC-133, 236, and 238) and papillary (TPC-1) carcinoma cells. Two different classes of MMP inhibitors were able to partially, and sometimes completely, block invasion at nontoxic doses, suggesting that MMPs are effectors of invasion in these cancer cells. Zymography yielded additional corroborative evidence, as all these cells were found to secrete active gelatinases. Col-3, which we have shown to inhibit MMP expression in our model, inhibited invasion more effectively than GM-6001, which acts only at the extracellular level. The failure of aprotinin to suppress invasion in this study suggests that serine proteases, though secreted by thyroid cancer cells (Smit et al. 1999), do not play a significant role in our model.

Our results link EGFR signaling to the augmentation of MMP-2 activation. MT1-MMP expression was increased two- to threefold by EGF, an effect that correlated closely with the appearance of active MMP-2 on zymography. Consistent with our findings, MMP-2 activation is known to parallel with MT1-MMP expression, as the latter is a cell surface activator of pro-MMP-2 (Butler et al. 1998). Little is known about the role of MMPs in the progression of thyroid carcinoma; however, MMP-2 activation (with activation ratios similar to those we report) and MT1-MMP expression correlate with the presence of lymph node metastases in papillary thyroid carcinomas (Nakamura et al. 1999). 


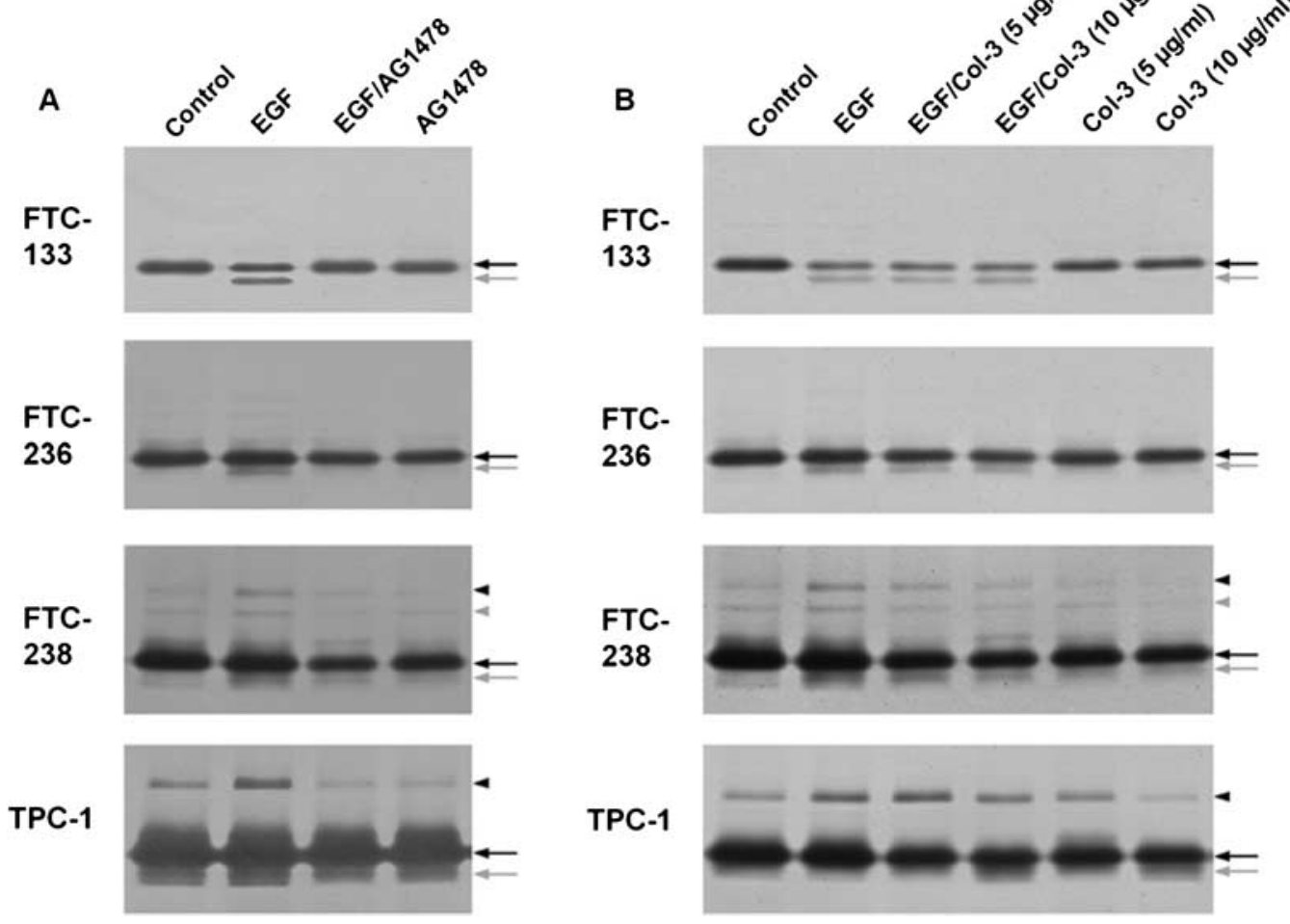

Figure 4 Effects of EGF (10 ng/ml), AG1478 $(2 \mu \mathrm{M})$, and Col-3 on gelatinase activities released by thyroid cancer cells. Lower bands indicate secretion of MMP-2 (gelatinase A), in $72 \mathrm{kDa}$ pro-form (black arrow) and $62 \mathrm{kDa}$ active form (gray arrow). Upper bands represent MMP-9 (gelatinase B) in 92 kDa pro-form (black arrowhead) and $82 \mathrm{kDa}$ active form (gray arrowhead).

Growth factors stimulate MMP-9 release in head and neck squamous cell carcinomas (O-charoenrat et al. 2000) and correlate with increased invasiveness in other cancer cell types (Price et al. 1996, Ueda et al. 1998, Harvey et al. 2000). A recent report demonstrated a link between activating mutations in the BRAF oncogene, commonly present in papillary thyroid carcinomas, with the upregulation of MMPs (Mesa et al. 2006).

The greatest changes in MMP mRNA levels involved MMP-9, which was upregulated 2.6-fold or greater by EGF. These findings must be interpreted in light of the generally low levels of MMP-9 mRNA expression and activity. The absence of MMP-9 activity in the presence of detectable mRNA levels may be explained by posttranscriptional regulation of MMP-9 (Piedagnel et al. 1999). TIMP-1 expression roughly paralleled the expression of MMPs, in agreement with reports on thyroid cancer cells and other cell types (Gomez et al. 1997, Soula-Rothhut et al. 2005). Degradation of the extracellular matrix (ECM) is determined by the balance of proteases and their inhibitors in the extracellular space (Yu et al. 1996). In our study, the net effects of EGF and Col-3 treatment on ECM degradation must be inferred from invasion assay results.
The effects of AG1478 on invasion, MMP expression, and MMP activation were mimicked by Col-3 in direction and magnitude, suggesting a similar mechanism of action. Col-3 generally displayed less potent effects than AG1478, raising the possibility that Col-3 may impact a subset of pro-invasive processes that are upregulated by EGF. In TPC cells, both AG1478 and MMP inhibitors suppressed invasion to below control levels, suggesting EGFR autoactivation in these cells. An autocrine loop involving TGF exists in papillary thyroid carcinomas and may be mediated through ADAM (a disintegrin and metalloproteinase) proteases (Haugen et al. 1993, Gee \& Knowlden 2003). Our results suggest that EGF induces differentiated thyroid cancer cell invasion via MMP-2 activation. MMPs represent an attractive target in cancer chemotherapy because of their multifaceted role in malignant progression, which encompasses central processes, such as invasion and angiogenesis (Chang \& Werb 2001). The cancer types most amenable to MMP inhibition will be those that rely heavily on the action of MMPs in relation to the other mechanisms of invasion. Here, we have shown that thyroid cancer cells fit this criterion. Col-3 is among the most 

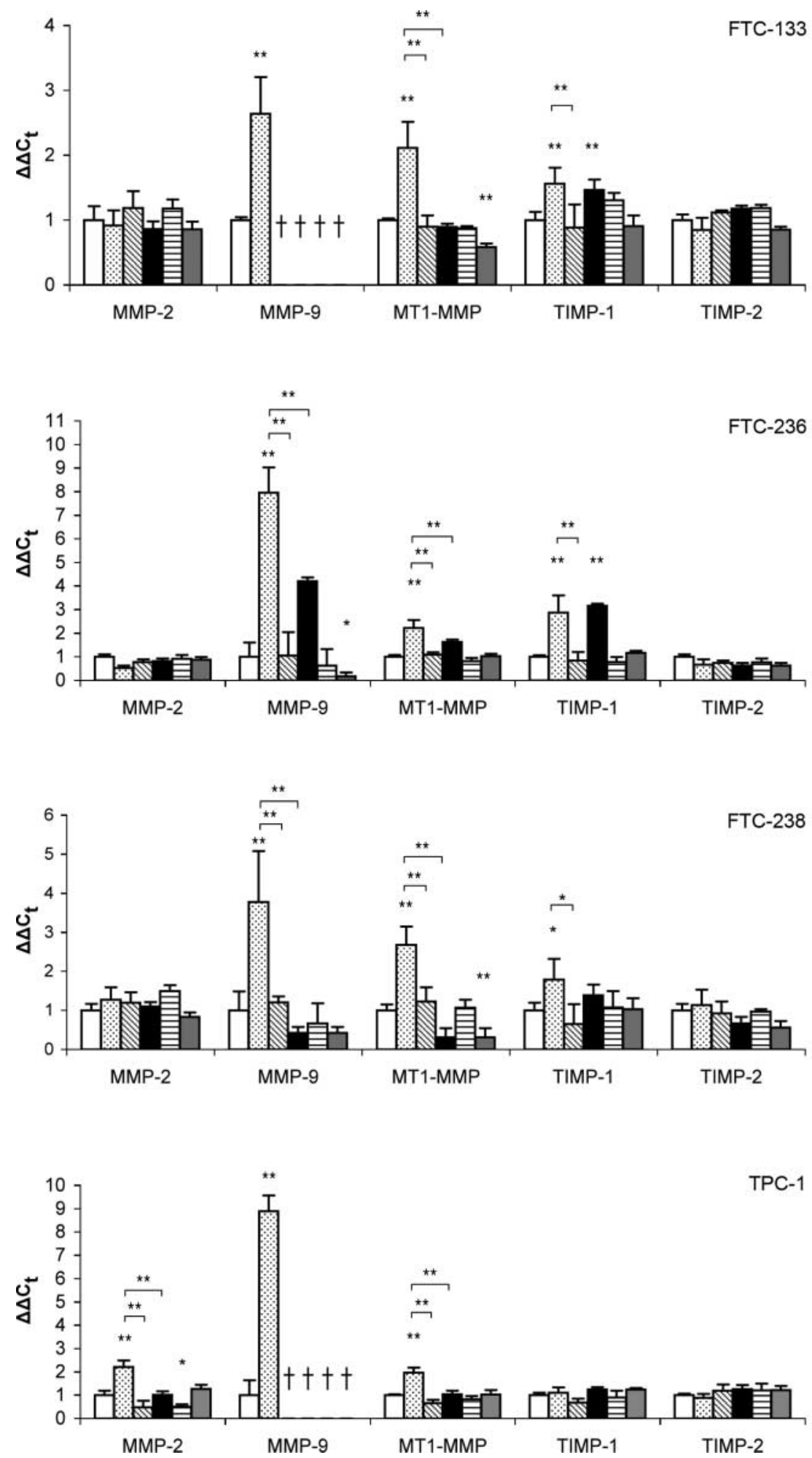

Figure 5 Relative expression of MMP and TIMP genes by quantitative real-time RT-PCR in thyroid cancer cells treated with EGF (10 ng/ml), AG1478 $(2 \mu \mathrm{M})$, and Col-3 $(10 \mu \mathrm{g} / \mathrm{ml})$. $Y$-axis, cDNA copy number relative to control (normalized to one in each case, scales vary); $X$-axis denotes individual genes. At least two RNA samples were used for each cell line. Brackets indicate pairwise comparisons. Unbracketed asterisks denote comparisons made to control. ${ }^{\star} P<0.005$, ${ }^{\star \star} P<0.0001$ by ANOVA (performed on $\Delta \Delta C_{\mathrm{t}}$ values). ${ }^{\dagger}$ Signifies expression below the limits of detection. 
promising of MMP inhibitors because of its high potency, oral bioavailability, and mild side effects (Rudek et al. 2001). Our results show that blockage of invasion occurs at clinically relevant dosages.

Agents targeting the EGFR may also be effective in advanced thyroid cancer, as interference with EGF signaling may inhibit the activation of MMP-2 and retard clinical progression. Monoclonal antibodies directed against the EGFR (cetuximab) and the small molecule tyrosine kinase inhibitors (gefitinib) have recently shown clinical activity against advanced solid tumors (El-Rayes \& LoRusso 2004), and a phase II clinical trial of gefitinib in advanced thyroid cancers is presently being conducted. Two recent preclinical studies have shown that EGFR-targeted agents inhibit growth of anaplastic thyroid cancer cells (Schiff et al. 2004, Nobuhara et al. 2005).

In summary, this study demonstrates that thyroid cancer cell invasion is regulated by the activation of MMP-2 downstream of the EGFR. We believe that inhibition of this pathway, at the level of the receptor or the expression of MMPs, may represent a promising novel therapy for advanced thyroid cancers. Further clinical investigation of this area is warranted.

\section{Acknowledgements}

This work was supported by the NIH T32 Surgical Oncology Training Grant, the American College of Surgeons Resident Research Scholarship, the Friends of Endocrine Surgery, and a grant from the National Cancer Institute (CA072006 to ZW). We thank David Ginzinger and William Hyun for their technical assistance. We also thank Peter Goretzki, Nobuo Satoh, Guy Juillard, and Brad Zerler for their provision of cell lines and reagents. The authors declare that there is no conflict of interest that would prejudice the impartiality of this scientific work.

\section{Disclosures}

The authors have no competing interests to disclose.

\section{References}

Akslen LA \& Varhaug JE 1995 Oncoproteins and tumor progression in papillary thyroid carcinoma: presence of epidermal growth factor receptor, c-erbB-2 protein, estrogen receptor related protein, p21-ras protein, and proliferation indicators in relation to tumor recurrences and patient survival. Cancer 76 1643-1654.

Albini A, Iwamoto Y, Kleinman HK, Martin GR, Aaronson SA, Kozlowski JM \& McEwan RN 1987 A rapid in vitro assay for quantitating the invasive potential of tumor cells. Cancer Research 47 3239-3245.
Behrendtsen O, Alexander CM \& Werb Z 1992 Metalloproteinases mediate extracellular matrix degradation by cells from mouse blastocyst outgrowths. Development 114 447-456.

Butler GS, Butler MJ, Atkinson SJ, Will H, Tamura T, van Westrum SS, Crabbe T, Clements J, d'Ortho MP \& Murphy G 1998 The TIMP2 membrane type 1 metalloproteinase 'receptor' regulates the concentration and efficient activation of progelatinase A. A kinetic study. Journal of Biological Chemistry 273 871-880.

Chang C \& Werb Z 2001 The many faces of metalloproteases: cell growth, invasion, angiogenesis and metastasis. Trends in Cell Biology 11 S37-S43.

Coussens LM, Fingleton B \& Matrisian LM 2002 Matrix metalloproteinase inhibitors and cancer: trials and tribulations. Science 295 2387-2392.

Dancey JE \& Freidlin B 2003 Targeting epidermal growth factor receptor - are we missing the mark? Lancet 362 62-64.

El-Rayes BF \& LoRusso PM 2004 Targeting the epidermal growth factor receptor. British Journal of Cancer 91 418-424.

Fagin JA, Matsuo K, Karmakar A, Chen DL, Tang SH \& Koeffler HP 1993 High prevalence of mutations of the p53 gene in poorly differentiated human thyroid carcinomas. Journal of Clinical Investigation 91 179-184.

Gee JM \& Knowlden JM 2003 ADAM metalloproteases and EGFR signalling. Breast Cancer Research 5 223-224.

Gomez DE, Alonso DF, Yoshiji H \& Thorgeirsson UP 1997 Tissue inhibitors of metalloproteinases: structure, regulation and biological functions. European Journal of Cell Biology 74 111-122.

Hanemaaijer R, Visser H, Koolwijk P, Sorsa T, Salo T, Golub LM \& van Hinsbergh VW 1998 Inhibition of MMP synthesis by doxycycline and chemically modified tetracyclines (CMTs) in human endothelial cells. Advances in Dental Research 12 114-118.

Harvey P, Clark IM, Jaurand MC, Warn RM \& Edwards DR 2000 Hepatocyte growth factor/scatter factor enhances the invasion of mesothelioma cell lines and the expression of matrix metalloproteinases. British Journal of Cancer $\mathbf{8 3}$ 1147-1153.

Haugen BR 1999 Management of the patient with progressive radioiodine non-responsive disease. Seminars in Surgical Oncology 16 34-41.

Haugen DR, Akslen LA, Varhaug JE \& Lillehaug JR 1992 Expression of c-erbB-2 protein in papillary thyroid carcinomas. British Journal of Cancer 65 832-837.

Haugen DR, Akslen LA, Varhaug JE \& Lillehaug JR 1993 Demonstration of a TGF-alpha-EGF-receptor autocrine loop and c-myc protein over-expression in papillary thyroid carcinomas. International Journal of Cancer 55 37-43.

Heid CA, Stevens J, Livak KJ \& Williams PM 1996 Real time quantitative PCR. Genome Research 6 986-994.

Hipps DS, Hembry RM, Docherty AJ, Reynolds JJ \& Murphy G 1991 Purification and characterization of human 72-kDa gelatinase (type IV collagenase). Use of immunolocalisation to demonstrate the non-coordinate 
regulation of the 72-kDa and $95-\mathrm{kDa}$ gelatinases by human fibroblasts. Biological Chemistry Hoppe-Seyler 372 287-296.

Hodgson NC, Button J \& Solorzano CC 2004 Thyroid cancer: is the incidence still increasing? Annals of Surgical Oncology 11 1093-1097.

Hoelting T, Siperstein AE, Clark OH \& Duh QY 1994 Epidermal growth factor enhances proliferation, migration, and invasion of follicular and papillary thyroid cancer in vitro and in vivo. Journal of Clinical Endocrinology and Metabolism 79 401-408.

Johansson N, Ahonen M \& Kahari VM 2000 Matrix metalloproteinases in tumor invasion. Cellular and Molecular Life Sciences 57 5-15.

Jossart GH, Epstein HD, Shaver JK, Weier HU, Greulich KM, Tezelman S, Grossman RF, Siperstein AE, Duh QY \& Clark OH 1996 Immunocytochemical detection of p53 in human thyroid carcinomas is associated with mutation and immortalization of cell lines. Journal of Clinical Endocrinology and Metabolism 81 3498-3504.

Kajikawa K, Yasui W, Sumiyoshi H, Yoshida K, Nakayama H, Ayhan A, Yokozaki H, Ito H \& Tahara E 1991 Expression of epidermal growth factor in human tissues. Immunohistochemical and biochemical analysis. Virchows Archiv. A, Pathological Anatomy and Histopathology 418 27-32.

Mesa C Jr Mirza M, Mitsutake N, Sartor M, Medvedovic M, Tomlinson C, Knauf JA, Weber GF \& Fagin JA 2006 Conditional activation of RET/PTC3 and BRAFV600E in thyroid cells is associated with gene expression profiles that predict a preferential role of BRAF in extracellular matrix remodeling. Cancer Research 66 6521-6529.

Mosmann T 1983 Rapid colorimetric assay for cellular growth and survival: application to proliferation and cytotoxicity assays. Journal of Immunological Methods 65 55-63.

Nakamura H, Ueno H, Yamashita K, Shimada T, Yamamoto E, Noguchi M, Fujimoto N, Sato H, Seiki M \& Okada Y 1999 Enhanced production and activation of progelatinase A mediated by membrane-type 1 matrix metalloproteinase in human papillary thyroid carcinomas. Cancer Research 59 467-473.

Nicholson RI, Gee JM \& Harper ME 2001 EGFR and cancer prognosis. European Journal of Cancer 37 S9-S15.

Nobuhara Y, Onoda N, Yamashita Y, Yamasaki M, Ogisawa K, Takashima T, Ishikawa T \& Hirakawa K 2005 Efficacy of epidermal growth factor receptortargeted molecular therapy in anaplastic thyroid cancer cell lines. British Journal of Cancer 92 1110-1116.

O-charoenrat P, Modjtahedi H, Rhys-Evans P, Court WJ, Box GM \& Eccles SA 2000 Epidermal growth factor-like ligands differentially up-regulate matrix metalloproteinase 9 in head and neck squamous carcinoma cells. Cancer Research 60 1121-1128.

Piedagnel R, Murphy G, Ronco PM \& Lelongt B 1999 Matrix metalloproteinase 2 (MMP2) and MMP9 are produced by kidney collecting duct principal cells but are differentially regulated by SV40 large-T, arginine vasopressin, and epidermal growth factor. Journal of Biological Chemistry 274 1614-1620.

Price JT, Wilson HM \& Haites NE 1996 Epidermal growth factor (EGF) increases the in vitro invasion, motility and adhesion interactions of the primary renal carcinoma cell line, A704. European Journal of Cancer 32A 1977-1982.

Rudek MA, Figg WD, Dyer V, Dahut W, Turner ML, Steinberg SM, Liewehr DJ, Kohler DR, Pluda JM \& Reed E 2001 Phase I clinical trial of oral COL-3, a matrix metalloproteinase inhibitor, in patients with refractory metastatic cancer. Journal of Clinical Oncology 19584-592.

Salo T, Lyons JG, Rahemtulla F, Birkedal-Hansen H \& Larjava H 1991 Transforming growth factor-beta 1 up-regulates type IV collagenase expression in cultured human keratinocytes. Journal of Biological Chemistry 266 11436-11441.

Schiff BA, McMurphy AB, Jasser SA, Younes MN, Doan D, Yigitbasi OG, Kim S, Zhou G, Mandal M, Bekele BN et al. 2004 Epidermal growth factor receptor (EGFR) is overexpressed in anaplastic thyroid cancer, and the EGFR inhibitor gefitinib inhibits the growth of anaplastic thyroid cancer. Clinical Cancer Research 10 8594-8602.

Smit JW, van der Pluijm G, Romijn HA, Lowik CW, Morreau H \& Goslings BM 1999 Degradation of extracellular matrix by metastatic follicular thyroid carcinoma cell lines: role of the plasmin activation system. Thyroid 9 913-919.

Soula-Rothhut M, Coissard C, Sartelet H, Boudot C, Bellon G, Martiny L \& Rothhut B 2005 The tumor suppressor PTEN inhibits EGF-induced TSP-1 and TIMP1 expression in FTC-133 thyroid carcinoma cells. Experimental Cell Research 304 187-201.

Ueda M, Fujii H, Yoshizawa K, Terai Y, Kumagai K, Ueki K \& Ueki M 1998 Effects of EGF and TGF-alpha on invasion and proteinase expression of uterine cervical adenocarcinoma OMC-4 cells. Invasion \& Metastasis 18 176-183.

Wright PA, Lemoine NR, Goretzki PE, Wyllie FS, Bond J, Hughes C, Roher HD, Williams ED \& Wynford-Thomas D 1991 Mutation of the p53 gene in a differentiated human thyroid carcinoma cell line, but not in primary thyroid tumours. Oncogene 6 1693-1697.

Yu AE, Hewitt RE, Kleiner DE \& Stetler-Stevenson WG 1996 Molecular regulation of cellular invasion - role of gelatinase A and TIMP-2. Biochemistry and Cell Biology 74 823-831.

Zielke A, Tezelman S, Jossart GH, Wong M, Siperstein AE, Duh QY \& Clark OH 1998 Establishment of a highly differentiated thyroid cancer cell line of Hürthle cell origin. Thyroid $\mathbf{8} 475-483$.

Zielke A, Hoffmann S, Plaul U, Duh QY, Clark OH \& Rothmund M 1999 Pleiotropic effects of thyroid stimulating hormone in a differentiated thyroid cancer cell line. Studies on proliferation, thyroglobulin secretion, adhesion, migration and invasion. Experimental and Clinical Endocrinology \& Diabetes 107 361-369. 